\title{
Corrigendum
}

\section{Involvement of RARRES3 in the regulation of Wnt proteins acylation and signaling activities in human breast cancer cells}

T-H Hsu, S-Y Jiang, W-L Chang, RL Eckert, TM Scharadin and T-C Chang

Cell Death and Differentiation (2015) 22, 1561; doi:10.1038/cdd.2015.90

Correction to: Cell Death and Differentiation (2015) 22, 801-814; doi:10.1038/cdd.2014.175; published online 7 November 2014
Since the publication of this article the authors have noted an error in the list of author names. W-L Chan should be W-L Chang. The correct list is shown above.

The authors apologize for any inconvenience caused. 